\title{
Potential of Ceria-Based Catalysts for the Oxidation of Landfill Leachate by Heterogeneous Fenton Process
}

\author{
E. Aneggi, ${ }^{1}$ V. Cabbai, ${ }^{1}$ A. Trovarelli, ${ }^{2}$ and D. Goi ${ }^{3}$ \\ ${ }^{1}$ Department of Chemistry, Physics and Environment, University of Udine, Via del Cotonificio, 108-331100 Udine, Italy \\ ${ }^{2}$ Catalysis Group, Department of Chemistry, Physics and Environment, University of Udine, Via del Cotonificio, \\ 108-331100 Udine, Italy \\ ${ }^{3}$ Civil Environmental Group, Department of Chemistry, Physics and Environment, University of Udine, Via del Cotonificio, \\ 108-331100 Udine, Italy
}

Correspondence should be addressed to D. Goi, goi@uniud.it

Received 26 May 2012; Accepted 22 July 2012

Academic Editor: Meenakshisundaram Swaminathan

Copyright () 2012 E. Aneggi et al. This is an open access article distributed under the Creative Commons Attribution License, which permits unrestricted use, distribution, and reproduction in any medium, provided the original work is properly cited.

In this study, ceria and ceria-zirconia solid solutions were tested as catalyst for the treatment of landfill leachate with a Fenton-like process. The catalysts considered in this work were pure ceria and ceria-zirconia solid solutions as well as iron-doped samples. All the catalysts were extensively characterized and applied in batch Fenton-like reactions by a close batch system, the COD (chemical oxygen demand) and TOC (total organic carbon) parameters were carried out before and after the treatments in order to assay oxidative abatement. Results show a measurable improvement of the TOC and COD abatement using ceria-based catalysts in Fenton-like process and the best result was achieved for iron-doped ceria-zirconia solid solution. Our outcomes point out that heterogeneous Fenton technique could be effectively used for the treatment of landfill leachate and it is worth to be the object of further investigations.

\section{Introduction}

Landfill leachate is a liquid waste of primary environmental concern because of the quantity and quality of the harmful pollutants contained in it. There are a large number of various types of organic and inorganic substances, depending on the age and type of solid wastes located in the landfill. Leachate from sanitary landfills can be an important source of ground water contamination and for this reason it is collected from the bottom of the landfill to be treated; further, this highly contaminated liquid waste accumulates a great diversity of harmful pollutants. Some of them are particularly refractory and for this reason traditional wastewater treatment plants are not efficient in their abatement. Inorganic and organic content of leachate is characteristically related to environmental risk because of scarce biodegradation, severe bioaccumulation, and potential health damages $[1,2]$. It is well known that conventional biological liquid waste treatments alone are unable to achieved complete removal of the leachate pollution over the life of the landfill.
In truth conventional biological processes are time consuming and low-efficiency methods to treat directly leachate, consequently physicochemical processes are frequently utilized to pretreat this liquid waste in order to reduce organic refractory before biological action in treatment plants units [3].

The most employed and studied methods in landfill leachate pretreatment are chemical or electrochemical coagulation [4], precipitation [5], and oxidation [6, 7]. Among these, a particular attention is given to oxidation techniques and especially to advanced oxidation processes (AOPs).

AOPs are methods able to convert nonbiodegradable organic pollutants into nontoxic biodegradable forms $[8,9]$, by the production of highly oxidizing hydroxyl radical species that promptly oxidize organic pollutants by a broad range of actions.

As a matter of fact oxidation by hydroxyl radicals species can be activated starting from $\mathrm{H}_{2} \mathrm{O}_{2}$ by intervention of transition metal salts (e.g., iron salts) [10], from ozone [11] or UV-light [12], leading to a more effective method to 
decompose certain refractory contaminants of leachate. In particular, Fenton oxidation is a well-known AOP used as pretreatment of leachate worldwide [10].

The Fenton's reagent works at mild temperature and pressure generating hydroxyl radicals following the generally accepted structure of reactions:

$$
\begin{gathered}
\mathrm{Fe}^{2+}+\mathrm{H}_{2} \mathrm{O}_{2} \longrightarrow \mathrm{Fe}^{3+}+\mathrm{OH}^{\bullet}+\mathrm{OH}^{-} \\
\mathrm{RH}+\mathrm{OH}^{\bullet} \longrightarrow \mathrm{H}_{2} \mathrm{O}+\mathrm{R}^{\bullet} \\
\mathrm{R}^{\bullet}+\mathrm{Fe}^{3+} \text {-oxidation } \longrightarrow \mathrm{R}^{+}+\mathrm{Fe}^{2+}
\end{gathered}
$$

This reaction is followed by other very complex oxidation reactions in which a lot of radical forms are generated and take part in the overall Fenton oxidation. The $\mathrm{H}_{2} \mathrm{O}_{2}$ can act both as a scavenger or initiator, all organics in liquid waste can participate in radical generation [10] and the ferric iron catalyzes and decomposes $\mathrm{H}_{2} \mathrm{O}_{2}$ to additional radical forms contributing to the oxidation [13]. Moreover, the reaction of ferrous iron forms ferric hydroxo complexes which can contribute to the coagulation capacity of the Fenton reagent [14]. The reactions including hydrogen peroxide and ferric ions or other transition metal ions are also reported as Fenton-like reactions $[15,16]$; moreover, some new wet peroxidations, in which various catalysts are added with hydrogen peroxide to remove organic compounds by low temperature reactions, are presented as heterogeneous Fenton-like systems [17-19].

The Fenton process is one of the most interesting AOPs when it is used to treat or pretreat heavily contaminated liquid wastes, and a lot of full-scale applications are installed over the world. The main advantage is to reach treatment of liquid wastes at mild conditions of temperature and pressure, but the most important drawback is the production of a sludge which needs to be treated as well. It is also a recognized concept that Fenton process, at reasonable reagents concentration, cannot lead to the complete mineralization of all organic compounds and often only partial oxidation occurs even in assisted oxidations [20].

Leachate treatment by classic Fenton process was often studied to assay potential increase of the biodegradability or reduction of toxicity or color removal [21-23]. Recently, photo-Fenton [24] and electro-Fenton [25] processes have been investigated for landfill leachate treatment and several studies have been dedicated to heterogeneous Fenton treatment of phenolic $[19,26,27]$ or industrial wastewater [2831]. Heterogeneous process could be a promising alternative due to the more important drawback of classic Fenton, the large amount of iron required for the reaction that dramatically exceeds the legally quantity permitted for effluent discharge $(<2 \mathrm{mg} / \mathrm{L})$ and consequently requires a final waste management. At present, at the best of our knowledge, only one experience is reported about leachate treatment by heterogeneous catalytic Fenton-like systems [32], which can potentially be a promising way to activate radicals oxidizing species with minor sludge production. The experience reported in this paper tries to give a contribution to this theme.

The use of ceria-based materials in catalytic science is well established $[33,34]$. Ceria is presently used in a large number of industrial processes and it accounts for a large part of the rare earth oxide market. Undoubtedly, its major commercial application is in the treatment of emissions from internal combustion engines where ceria-based materials have been used in the past 30 years [35]. Its more important action in three-way catalysts (TWCs) is to take up and release oxygen following variations in the stoichiometric composition of the feedstream; however, several other processes also benefit from the use of cerium and its derivates. Organosoluble compounds of cerium are used as fuel additives for diesel engines and industrial boilers to reduce carbon deposits after combustion. Cerium oxide is used also as a catalytically active component to oxidize the liquid portion of particulate present in diesel engine exhaust. $\mathrm{CeO}_{2}$ is also used as an additive or a promoter in commercial applications such as fluid catalytic cracking, ammoxidation and dehydrogenation processes [33-37]. Moreover, in the last years several ceriabased catalysts were investigated for CWAO (catalytic wet air oxidation) [38-40] and CWOP (catalytic wet peroxide oxidation) [41-44] techniques. The main purpose of this work is to investigate doped ceria materials in the treatment of landfill leachate by a heterogeneous Fenton process.

\section{Materials and Methods}

2.1. Characterization and Sampling of Landfill Leachate. The leachate used in this study was drawn from an aged landfill near the city of Udine (northeast Italy); the landfill is not equipped with a recirculation system and it produces a stable leachate with high concentrations of COD and low BOD/ COD ratio with a brown-green color. All the measures are carried out following the Standard Methods for the Examination of Water and Wastewater [45], COD was determined by colorimetric method utilizing a Hach Lange-DR 5000 spectrophotometer and quenching measurable residual $\mathrm{H}_{2} \mathrm{O}_{2}$ to prevent interference by addition of $\mathrm{MnO}_{2}(\mathrm{~s})$. Residual $\mathrm{H}_{2} \mathrm{O}_{2}$ was checked and determined to be zero by using test strips (Peroxide test sticks Quantofix, Sigma Aldrich). The TOC analyses were performed by a TOC-VCPN, Shimadzu analyzer.

2.2. Preparation and Characterization of the Catalysts. The catalysts, ceria $\left(\mathrm{CeO}_{2}, \mathrm{CZ100}\right)$, ceria-zirconia solid solutions $\left(\mathrm{Ce}_{0.44} \mathrm{Zr}_{0.56} \mathrm{O}_{2}, \mathrm{CZ44}\right)$ and Fe-doped materials $\left(\mathrm{Ce}_{0.85} \mathrm{Fe}_{0.15} \mathrm{O}_{1.925}, \mathrm{CF}\right.$ and $\left.\mathrm{Ce}_{0.45} \mathrm{Zr}_{0.40} \mathrm{Fe}_{0.15} \mathrm{O}_{1.925}, \mathrm{CZF}\right)$ were prepared by coprecipitation starting from nitrates. Precipitates were dried at $393 \mathrm{~K}$ and calcined at $773 \mathrm{~K}$ for $2 \mathrm{~h}$. Fedoped materials were also calcined at higher temperature $(1073 \mathrm{~K})$ to investigate the behavior of iron-phase in the system.Textural characteristics of all samples were measured according to the BET method by nitrogen adsorption at $77 \mathrm{~K}$, using a Tristar 3000 gas adsorption analyzer (Micromeritics).

Structural features of the catalysts were characterized by $\mathrm{X}$-ray diffraction (XRD). XRD patterns were recorded on a Philips X'Pert diffractometer operated at $40 \mathrm{kV}$ and $40 \mathrm{~mA}$ using nickel-filtered $\mathrm{Cu}-\mathrm{K}_{\alpha}$ radiation. Spectra were collected using a step size of $0.02^{\circ}$ and a counting time of $40 \mathrm{~s}$ per angular abscissa in the range $20^{\circ}-145^{\circ}$. The Philips X'Pert 


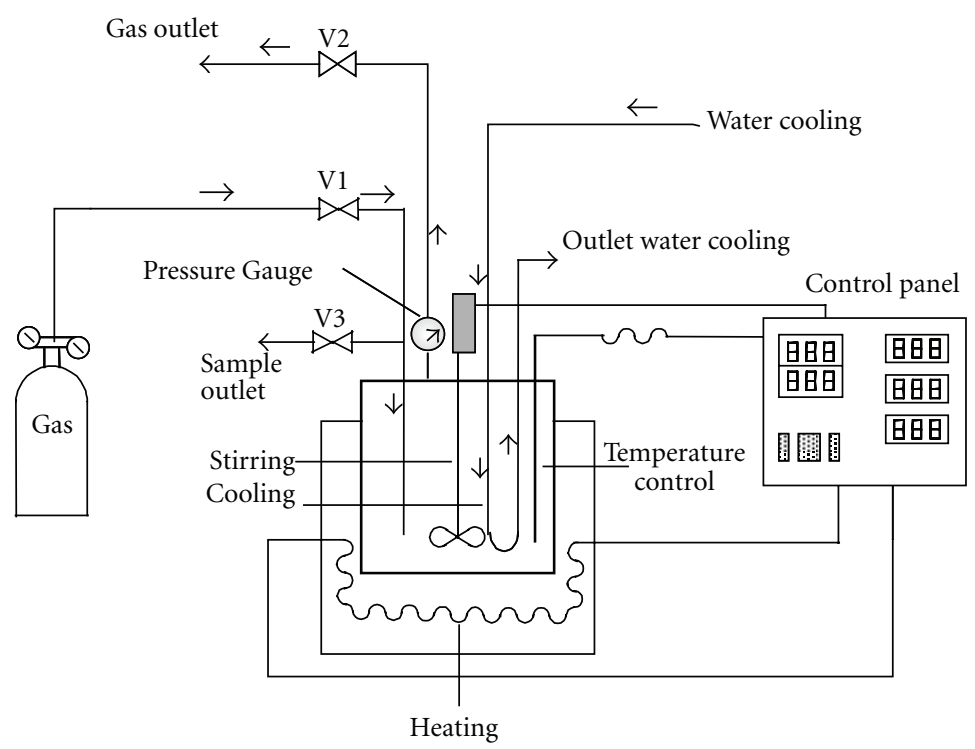

Figure 1: Schematic representation of the batch oxidation reactor used for tests.

HighScore software was used for phase identification. The mean crystalline size was estimated from the full width at the half maximum (FWHM) of the X-ray diffraction peak using the Scherrer equation [46] with a correction for instrument line broadening. Rietveld refinement [47] of XRD pattern was performed by means of GSAS-EXPGUI program [48, 49]. The accuracy of these values was estimated by checking their agreement against the values of the lattice constant, assumed to comply with the Vegard's law [50].

In order to evaluate the oxygen/storage capacity (OSC) of samples TGA, experiments in $\mathrm{Ar} / \mathrm{H}_{2}$ (5\%) flow (total flow $100 \mathrm{~mL} / \mathrm{min}$ ) were carried out. Each sample was treated in $\mathrm{N}_{2}$ atmosphere for $1 \mathrm{~h}$ at $553 \mathrm{~K}$. Then, it was heated at a constant rate $(10 \mathrm{~K} / \mathrm{min})$ till $673 \mathrm{~K}$ and kept at this temperature for 15 minutes, to eliminate the absorbed water. Finally, $\mathrm{Ar} / \mathrm{H}_{2}$ mixture was introduced while keeping the temperature at $673 \mathrm{~K}$ for 30 minutes. The observed weight loss is due to oxygen removal by $\mathrm{H}_{2}$ to form water, and it can be associated to total oxygen storage capacity at that temperature $[51,52]$.

\subsection{Catalytic Activity}

2.3.1. Heterogeneous Fenton. A pressure vessel (Parr Instruments) equipped with a glass batch reactor with continuous stirring (400 rpm) (Figure 1) was used to carry out Fentonlike oxidative reactions. The experiments were conducted for 120 minutes at $343 \mathrm{~K}$ stirring $100 \mathrm{~mL}$ of leachate with $10 \mathrm{mg}$ of catalysts and $5 \mathrm{~mL}$ of $\mathrm{H}_{2} \mathrm{O}_{2}(3 \%)$. At the end of the reaction ( 2 hours), samples were taken out and analyzed. Each experiment was repeated three times to obtain the reproducibility (error bars are included in figures).

\section{Results and Discussion}

3.1. Textural and Structural Characterization. The leachate selected to test oxidative Fenton-like process was characterized by a small concentration of iron in the raw mixture,
TABLE 1: Characterization of the landfill leachate used in this study.

\begin{tabular}{lcc}
\hline Parameter & Unit of measurement & Values \\
\hline $\mathrm{pH}$ & - & 9 \\
$\mathrm{BOD}_{5}$ & $\mathrm{mg} \mathrm{O}_{2} / \mathrm{L}$ & 60 \\
$\mathrm{COD}$ & $\mathrm{mg} \mathrm{O}_{2} / \mathrm{L}$ & 2500 \\
$\mathrm{BOD}_{5} / \mathrm{COD}$ & - & 0.024 \\
$\mathrm{TN}$ & $\mathrm{mg} \mathrm{N} / \mathrm{L}$ & 1860 \\
$\mathrm{TOC}$ & $\mathrm{mg} \mathrm{C} / \mathrm{L}$ & 575 \\
$\mathrm{AOS}$ & - & -2.52 \\
$\Delta \mathrm{OD}$ & $\mathrm{mg} \mathrm{O}_{2} / \mathrm{L}$ & 0.38 \\
Ammonia & $\mathrm{mg} \mathrm{NH}_{4}{ }^{+} / \mathrm{L}$ & 2150 \\
Chloride & $\mathrm{mg} \mathrm{Cl}^{-} / \mathrm{L}$ & - \\
Color & $\mathrm{PtCo} \mathrm{unit}^{-}$ & 3600 \\
Total iron & $\mathrm{mg} \mathrm{Fe}^{2} / \mathrm{L}$ & 1.2 \\
Nitrate & $\mathrm{mg} \mathrm{NO}_{3} / \mathrm{L}$ & - \\
Orthophosphate & $\mathrm{mg} \mathrm{PO}_{4}{ }^{-} / \mathrm{L}$ & 60 \\
Sulfate & $\mathrm{mg} \mathrm{SO}_{4}{ }^{2-} / \mathrm{L}$ & - \\
\hline
\end{tabular}

a high $\mathrm{pH}$ value, a slight high value of COD and TOC if compared to average values of other old landfill leachate [53]. The main properties are described in Table 1.

Textural and structural characterization of all catalysts is reported in Table 2. Materials have surface area in the range 55-135 m²/g. Ceria-zirconia solid solutions (CZ44 and CZF) show higher surface area with respect to ceria-based samples (CZ100 and CF) due to the stabilization effect of zirconia.

The introduction of $\mathrm{ZrO}_{2}$ significantly enhances textural properties, indeed, sintering in ceria-zirconia is less important in accordance with its better thermal resistance [54].

Doping ceria has a significant positive effect on the catalytic, oxygen storage/redox and thermal properties of catalysts. The introduction of $\mathrm{Zr}^{4+}$ induces a structural modification and this factor plays a key role in the redox 
TABLE 2: Characteristics of catalysts used in this study and crystallographic parameters of modified ceria samples as obtained from Rietveld refinement and Vegard's law.

\begin{tabular}{|c|c|c|c|c|c|c|}
\hline \multirow{2}{*}{ Sample } & \multirow{2}{*}{ Composition } & \multirow{2}{*}{ BET surface area $\left(\mathrm{m}^{2} / \mathrm{g}\right)$} & \multirow{2}{*}{ Crystallite size $(\mathrm{nm})^{\mathrm{a}}$} & \multirow{2}{*}{ Phase } & \multicolumn{2}{|c|}{ Cell parameter } \\
\hline & & & & & $a=b=c(\AA)$ & From Vegard's law \\
\hline CZ100 & $\mathrm{CeO}_{2}$ & 53 & 7 & Cubic & $5.411(1)$ & 5.411 \\
\hline CZ44 & $\mathrm{Ce}_{0.44} \mathrm{Zr}_{0.56} \mathrm{O}_{2}$ & 90 & 4.7 & Cubic & $5.281(1)$ & 5.285 \\
\hline $\mathrm{CF}$ & $\mathrm{Ce}_{0.85} \mathrm{Fe}_{0.15} \mathrm{O}_{1.925}$ & 77 & 7.5 & Cubic & $5.396(1)$ & 5.263 \\
\hline CF $(1073 \mathrm{~K})$ & $\mathrm{Ce}_{0.85} \mathrm{Fe}_{0.15} \mathrm{O}_{1.925}$ & 22 & 31.1 & Cubic & $5.408(1)$ & 5.263 \\
\hline $\mathrm{CZF}$ & $\mathrm{Ce}_{0.45} \mathrm{Zr}_{0.40} \mathrm{Fe}_{0.15} \mathrm{O}_{1.925}$ & 132 & 3.5 & Cubic & $5.295(1)$ & 5.163 \\
\hline CZF (1073 K) & $\mathrm{Ce}_{0.45} \mathrm{Zr}_{0.40} \mathrm{Fe}_{0.15} \mathrm{O}_{1.925}$ & 22 & 8.9 & Cubic & $5.292(1)$ & 5.163 \\
\hline
\end{tabular}

${ }^{\mathrm{a}}$ Calculated with Scherrer formula from X-ray diffraction patterns.

behaviour of ceria-zirconia solid solutions. The substitution of $\mathrm{Ce}^{4+}$ with $\mathrm{Zr}^{4+}$ produces a contraction of the cell volume and induces stress in the structure and consequently structural defects that increase the oxygen mobility. It is important to point out that the oxygen mobility is increased if no modification in the structure of solid solution is observed. From these considerations, we noted that better performances are achieved for solid solutions with cubic symmetry and with a high level of $\mathrm{Zr}^{4+}$. Alternatively, a higher amount of $\mathrm{ZrO}_{2}$ decreases the number of redox sites and consequently the activity of the system. There is an inverse relationship between the two effects; in order to obtain an active system it is important to balance the amount of structural defects and the amount of ceria. Literature data suggest that better results are obtained for compositions between CZ50 and CZ90 [5558]. XRD.

The structural features of all samples were analyzed by

In $\mathrm{CeO}_{2}-\mathrm{ZrO}_{2}$ system, several phases could be formed, depending on preparation conditions and concentration of single-oxide constituents [59]. In general, for a $\mathrm{CeO}_{2}$ content $<20 \mathrm{~mol} \%$ a single-phase monoclinic cell is observed, while in $\mathrm{CeO}_{2}$-rich compositions $\left(\mathrm{CeO}_{2}>70 \mathrm{~mol} \%\right)$ solid solutions of cubic symmetry are formed. At intermediate levels, regions of tetragonal ( $t, t^{\prime}$, and $t^{\prime \prime}$ phases) and cubic symmetry coexist in the phase diagram, their formation depending on the preparation method used. In our case, the Rietveld analysis of the diffraction profile of the materials has been carried out by opening the fitting to cubic, tetragonal and a mixture of the two.

As shown in Table 2, XRD measurements suggest that for binary ceria-zirconia samples with cerium content greater than $40 \mathrm{~mol} \%$ the formation of a cubic fluorite lattice is favored, in accordance with the literature [60]. Thus, our ceria and ceria-zirconia solid solution crystallize in a cubic fluorite structure of Fm3m symmetry. In CZ44, no peak splitting that would indicate the presence of two phases could be detected, and therefore, the diffraction patterns demonstrate the formation of a single solid solution-like ceriazirconia phase. This cannot exclude the presence of different arrangements of oxygen sublattice or the presence of a multiphase system at a nanoscale level, not detected by XRD. In fresh samples doped with $\mathrm{Fe}, \mathrm{XRD}$ features allow to detect only the $\mathrm{CeO}_{2}$ or $\mathrm{Ce}_{0.44} \mathrm{Zr}_{0.56} \mathrm{O}_{2}$ cubic phase $\mathrm{Fm} 3 \mathrm{~m}$, while $\mathrm{Fe}_{2} \mathrm{O}_{3}$ or other iron oxide phases are not visible
(Figure 2(a)). XRD peaks are broad and the values of crystallite size obtained according to Scherrer equation are about $7.5 \mathrm{~nm}$ for sample CF and $3.5 \mathrm{~nm}$ for sample CZF. In order to understand better the structural properties of Fedoped system, CF and CZF catalysts were calcined at higher temperatures $(1023 \mathrm{~K})$.

After calcination, in the XRD profile of $\mathrm{CF}$, peaks assigned to rhombohedral $\mathrm{Fe}_{2} \mathrm{O}_{3}$ (hematite) with $R-3 c$ symmetry are visible (Figure 2(b)).

The lack of peak due to iron oxide in fresh CF samples could indicate the formation of solid solution between $\mathrm{Ce}$ and Fe. However, a comparison between lattice parameters retrieved from Rietveld refinement and from Vegard law (values of cell parameter expected if all the iron contained were dissolved in the lattice) indicates that only a small percentage of iron is dissolved in ceria (Table 2).

After aging, the increase of cell parameter indicates a segregation of the iron eventually dissolved in the lattice with formation of weak signal due to crystalline $\mathrm{Fe}_{2} \mathrm{O}_{3}$. It is known that lower valence ions such as $\mathrm{Fe}^{3+}$ are extremely difficult to dissolve into the ceria lattice, especially when treating at high temperature [61]. Mutual dissolution of $\mathrm{Ce}$ and $\mathrm{Fe}$ into $\mathrm{Fe}_{2} \mathrm{O}_{3}$ and $\mathrm{CeO}_{2}$ has been reported to exist in Fe-rich $\mathrm{Ce} / \mathrm{Fe}$ mixed oxides prepared by coprecipitation [62].

For CZF, the value of cell parameter retrieved by Rietveld refinement is not in agreement with that computed from Vegard's law: the adding of a cation $\left(\mathrm{Fe}^{3+}\right)$ with ionic radius smaller than $\mathrm{Ce}^{4+}$ and $\mathrm{Zr}^{4+}$ should produce a decrease in cell volume in the case of a solid solution. Conversely, we observe a value higher than expected indicating that $\mathrm{Fe}_{2} \mathrm{O}_{3}$ is probably deposited on the surface. Moreover, iron could be present as interstitial and/or extralattice or amorphous interparticle iron. As in the case of pure ceria, we cannot exclude that a small fraction of $\mathrm{Fe}$ is dissolved within ceriazirconia framework.

3.2. Catalytic Activity. We investigated the heterogeneous process on different ceria-based catalysts performing reactions at $343 \mathrm{~K}$ for 2 hours, without any $\mathrm{pH}$ correction of the leachate $(\mathrm{pH} 9)$. Preliminary tests were carried out in order to verify the activity of catalyst and/or $\mathrm{H}_{2} \mathrm{O}_{2}$. In absence of catalyst and $\mathrm{H}_{2} \mathrm{O}_{2}$ (Figure 3 ), the abatement of COD and TOC, due only to the thermal treatment at $343 \mathrm{~K}$, is small, respectively $1 \%$ and $14 \%$. 


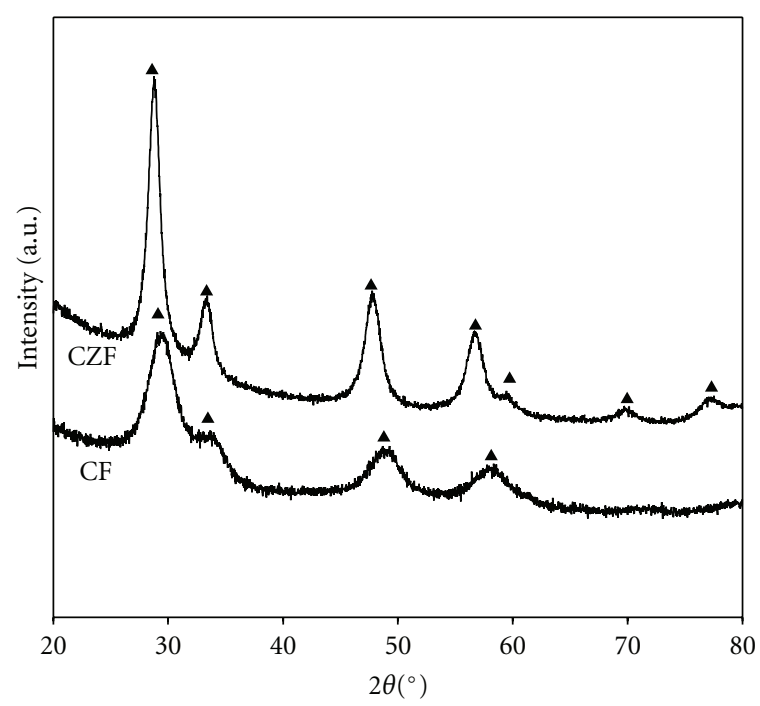

(a)

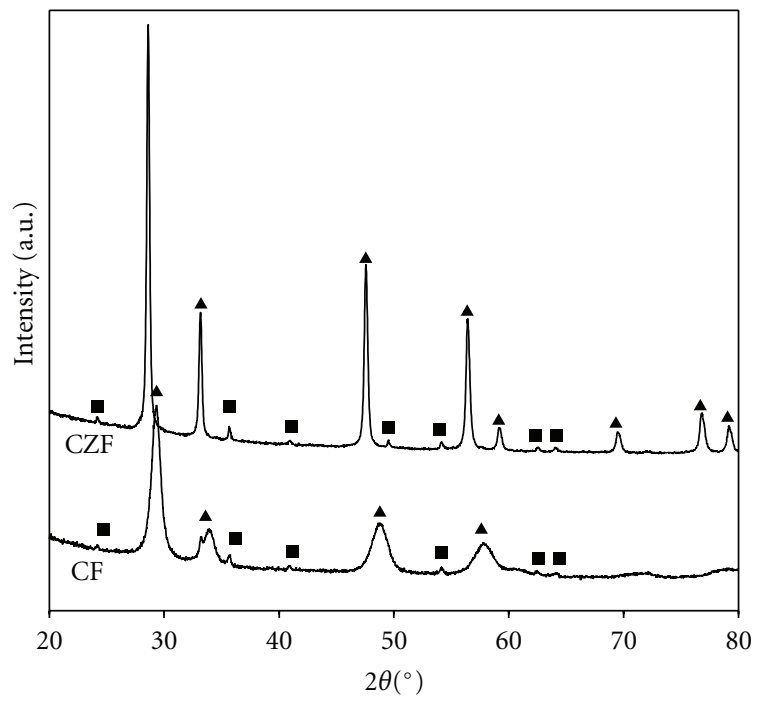

(b)

FIGURE 2: XRD profile for fresh (a) and aged (b) iron-doped samples $\left(\boldsymbol{\Lambda}: \mathrm{CeO}_{2}\right.$ and $\left.\mathrm{CeZrO}_{2} ; \mathbf{\square}: \mathrm{Fe}_{2} \mathrm{O}_{3}\right)$.

As shown in the plot, the advantage of the addition, for the abatement of COD and TOC, of bare ceria is negligible. In absence of the catalyst, but with $5 \mathrm{~mL}$ of $\mathrm{H}_{2} \mathrm{O}_{2}(3 \%)$, a small improvement in the activity was observed due to the oxidation capacity of the hydrogen peroxide alone. This activity could be explained considering that the small amount of iron presented in the leachate (Table 1) can interact with $\mathrm{H}_{2} \mathrm{O}_{2}\left(\mathrm{Fe} / \mathrm{H}_{2} \mathrm{O}_{2}\right.$ ratio was $\left.1: 687\right)$ catalyzing the formation of ${ }^{\bullet} \mathrm{OH}$ radicals as in the homogeneous Fenton. When pure ceria and hydrogen peroxide were used in combination, the catalytic activity was further improved reaching an abatement of COD and TOC of $7 \%$ and $30 \%$, respectively, confirming the positive synergic action of the two agents in the heterogeneous Fenton-like process. From these preliminary tests, we can conclude that ceria alone is not active and

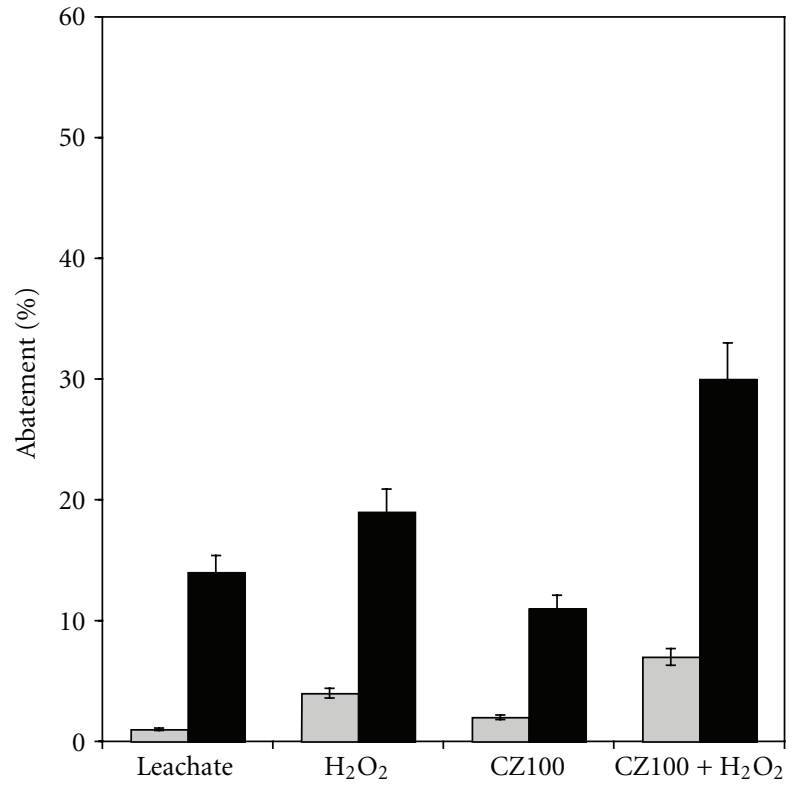

FIGURE 3: COD (light grey) and TOC (black) abatement for reaction with and without catalyst and $\mathrm{H}_{2} \mathrm{O}_{2}$ (reaction conditions: $10 \mathrm{mg}$ of catalyst, $5 \mathrm{~mL}$ of $\mathrm{H}_{2} \mathrm{O}_{2}, \mathrm{pH}=9, T=343 \mathrm{~K}$ ).

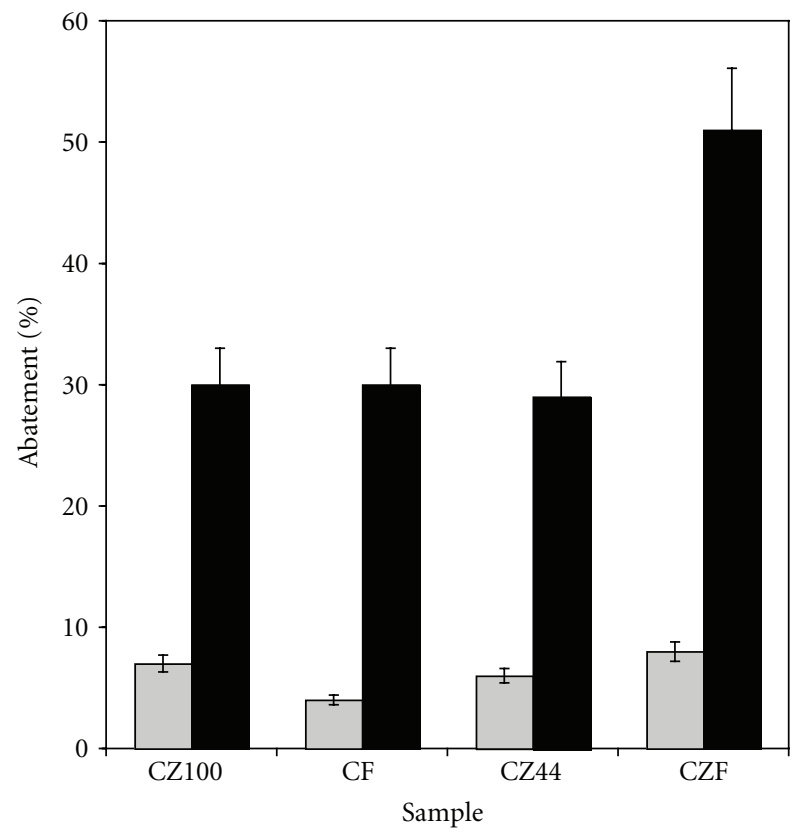

FIGURE 4: COD (light grey) and TOC (black) abatement for different catalysts (reaction conditions: $10 \mathrm{mg}$ of catalyst, $5 \mathrm{~mL}$ of $\mathrm{H}_{2} \mathrm{O}_{2}, \mathrm{pH}=9, \mathrm{~T}=343 \mathrm{~K}$ ).

a synergic action between catalyst and hydrogen peroxide is necessary to obtain higher performance.

After blank tests, the activity of the four ceria-based catalysts (CZ100, CZ44, CF, and CZF) was investigated and the results are shown in Figure 4.

Ceria and ceria-zirconia solid solutions show very similar results. The catalytic activity of ceria-based systems could 
be attributed to the capacity of cerium oxide to decompose $\mathrm{H}_{2} \mathrm{O}_{2}$, as reported in a previous study in which the decomposition of hydrogen peroxide, with formation of radical species, in an aqueous suspension of $\mathrm{CeO}_{2}$ was investigated [63]. The mechanism for $\mathrm{H}_{2} \mathrm{O}_{2}$ decomposition in the presence of water-oxide interfaces is still not completely elucidated, but it was suggested that it occurs on the surface with $\mathrm{OH}$ or $\mathrm{HO}_{2}$ radicals production.

The catalytic activity of cerium oxide is correlated with its oxygen storage capacity. One of the most important roles of $\mathrm{CeO}_{2}$ in catalytic redox reactions is to provide surface active sites [64] and to act as an oxygen storage/transport medium by its redox cycle between $\mathrm{Ce}^{4+}$ and $\mathrm{Ce}^{3+}$. That is, the presence of surface active oxygens from one side and the oxygen storage capacity from the other are among the most important factors to be considered. These, in turn, are strongly influenced by surface area and surface/bulk composition.

As pointed out previously, doping ceria with $\mathrm{Zr}^{4+}$ increase, the oxygen mobility, but a higher amount of $\mathrm{ZrO}_{2}$ decreases the number of redox sites and consequently the activity of the system. In order to explain the activity of the two systems, we need to take into account the right combination of surface area and composition.

For this reason, it is important to correlate overall activity with total available surface active oxygens, TSAO (which are linearly dependent on the amount of ceria) and total oxygen storage capacity, OSC (which generally shows a volcanotype relation with composition). The number of total surface oxygens (TSO) has been estimated according to Madier et al. [65] starting from the structure and the molar composition of the oxide considering the exposure of (100), (110), and (111) surfaces and assuming that Zr atoms do not participate in the redox process. The number of total surface available oxygens (TSAO) represents a fraction of total surface oxygens considering that only one atom out of four is involved in the $\mathrm{Ce}^{4+}-\mathrm{Ce}^{3+}$ redox process [65-67]. OSC data collected according to the method described in the experimental. Results are reported in Table 3.

Even though CZ100 has a lower surface area, pure ceria and CZ44 show almost the same value of TSAO $(225 \mu \mathrm{mol}$ $\mathrm{O} / \mathrm{g}$ and $182 \mu \mathrm{mol} \mathrm{O} / \mathrm{g}$, resp.). A more pronounced difference was found in OSC $\left(1669 \mu \mathrm{g} \mathrm{O} / \mathrm{g}\right.$ and $3721 \mu \mathrm{g} \mathrm{O}_{2} / \mathrm{g}$ for CZ100 and CZ44, resp.) that takes into account surface and bulk oxygens. In both catalysts, the surface area is quite high, consequently the abstraction of oxygen involves mainly surface sites, with little or no participation of the bulk in the reaction. Therefore, the more important factor is the availability of surface oxygen. In our materials (CZ100 and CZ44), the availability of surface oxygen is almost the same; therefore the two systems, CZ100 and CZ44, exhibit a very similar catalytic activity in the treatment of landfill leachate.

For CZF, the simultaneously presence of iron and zirconia significantly increased the abatement of TOC (51\%) but has no significant effect on COD.

CF sample is characterized by the formation of cubic ceria-like solid solution where Fe cations are dissolved within ceria structure. In this case, the interaction takes place
TABLE 3: TSAO and OSC for CZ100 and CZ44.

\begin{tabular}{lcc}
\hline Sample & TSAO $(\mu \mathrm{mol} \mathrm{O} / \mathrm{g})$ & OSC $\left(\mu \mathrm{g} \mathrm{O}_{2} / \mathrm{g}\right)$ \\
\hline CZ100 & 225 & 1669 \\
CZ44 & 182 & 3721 \\
\hline
\end{tabular}

through the sharing of oxygen anion defined by the Fe-O$\mathrm{Ce}$ bonds formed in the $\mathrm{Fe}$-doped $\mathrm{CeO}_{2}$ lattice [62]

In CZF sample, the lack of these interactions due to the lower amount of ceria and consequently to the lower amount of $\mathrm{Ce}-\mathrm{Fe}-\mathrm{O}$ entities formed in the system, can explain the different behavior of this catalyst. Indeed, in this case, a higher amount of Fe (due to weaker interaction with $\mathrm{Ce}$ and to the amorphous $\mathrm{Fe}_{2} \mathrm{O}_{3}$ phase on the surface) is available for the reaction with the leachate.

Our research pointed out the good activity of ceria-based heterogeneous treatment and we can conclude that ceria based catalyst is a very promising class of materials for this kind of application.

Further studies will be dedicated to a better understanding of the mechanism of reaction of ceria-based catalyst and to the optimization of the reaction conditions and catalytic stability.

\section{Conclusions}

Our study shows that the heterogeneous Fenton process could be successfully used in the treatment of landfill leachate substituting homogeneous treatment. Promising results were obtained in leachate oxidation by a heterogeneous Fentonlike process over ceria-based catalysts with an abatement of TOC higher than 50\%.

This is just a first investigation into the potentiality of heterogeneous reaction, but the results appear encouraging. In heterogeneous reactions, several variables are involved and need to be completely understood for a good optimization of the catalyst. Further studies will be dedicated to a better understanding of the mechanism of reaction of ceria-based catalysts and the role of iron and zirconia in the reactions and leaching. Moreover, we need to optimize the reaction conditions, such as $\mathrm{pH}$, temperature, and catalyst/peroxide ratio. Additional investigations should be performed in order to deeply explore a promising technique such as heterogeneous Fenton. At the moment, several aspects need to be investigated in more detail, but the results open a new field of research and point out a very interesting class of catalyst that could be used for landfill leachate treatment and worthy to be the subject of further investigations.

\section{Acknowledgments}

The authors thank financial support from AMGA Spa, Udine and Passavant Impianti Spa, Milan. They are also grateful to Dott. Stefano Turco and Mr. Aldo Bertoni for laboratory help. 


\section{References}

[1] L. H. Keith and W. A. Teliard, "Priority pollutants: a perspective view," Environmental Science \& Technology, vol. 13, pp. 416-423, 1979.

[2] K. Knox and P. H. Jones, "Complexation characteristics of sanitary landfill leachates," Water Research, vol. 13, no. 9, pp. 839-846, 1979.

[3] M. Hagman, E. Heander, and J. L. C. Jansen, "Advanced oxidation of refractory organics in leachate-potential methods and evaluation of biodegradability of the remaining substrate," Environmental Technology, vol. 29, no. 9, pp. 941-946, 2008.

[4] C. Papastavrou, D. Mantzavinos, and E. Diamadopoulos, "A comparative treatment of stabilized landfill leachate: coagulation and activated carbon adsorption vs. electrochemical oxidation," Environmental Technology, vol. 30, no. 14, pp. 1547-1553, 2009.

[5] N. Meunier, P. Drogui, C. Montané, R. Hausler, G. Mercier, and J. F. Blais, "Comparison between electrocoagulation and chemical precipitation for metals removal from acidic soil leachate," Journal of Hazardous Materials, vol. 137, no. 1, pp. 581-590, 2006.

[6] F. J. Rivas, F. Beltrán, F. Carvalho, B. Acedo, and O. Gimeno, "Stabilized leachates: sequential coagulation-flocculation plus chemical oxidation process," Journal of Hazardous Materials, vol. 116, no. 1-2, pp. 95-102, 2004.

[7] M. J. K. Bashir, M. H. Isa, S. R. M. Kutty et al., "Landfill leachate treatment by electrochemical oxidation," Waste Management, vol. 29, no. 9, pp. 2534-2541, 2009.

[8] E. Khan, R. W. Babcock, T. M. Hsu, and H. Lin, "Mineralization and biodegradability enhancement of low level p-nitrophenol in water using Fenton's reagent," Journal of Environmental Engineering, vol. 131, no. 2, pp. 327-331, 2005.

[9] E. C. Catalkaya and F. Kargi, "Advanced oxidation of diuron by photo-fenton treatment as a function of operating parameters," Journal of Environmental Engineering, vol. 134, no. 12, pp. 1006-1013, 2008.

[10] E. Neyens and J. Baeyens, "A review of classic Fenton's peroxidation as an advanced oxidation technique," Journal of Hazardous Materials, vol. 98, no. 1-3, pp. 33-50, 2003.

[11] P. Westerhoff, G. Aiken, G. Amy, and J. Debroux, "Relationships between the structure of natural organic matter and its reactivity towards molecular ozone and hydroxyl radicals," Water Research, vol. 33, no. 10, pp. 2265-2276, 1999.

[12] S. Zhao, H. Ma, M. Wang et al., "Role of primary reaction initiated by $254 \mathrm{~nm}$ UV light in the degradation of pnitrophenol attacked by hydroxyl radicals," Photochemical and Photobiological Sciences, vol. 9, no. 5, pp. 710-715, 2010.

[13] J. De Laat and H. Gallard, "Catalytic decomposition of hydrogen peroxide by $\mathrm{Fe}(\mathrm{III})$ in homogeneous aqueous solution: mechanism and kinetic modeling," Environmental Science and Technology, vol. 33, no. 16, pp. 2726-2732, 1999.

[14] S. H. Lin and C. C. Lo, "Fenton process for treatment of desizing wastewater," Water Research, vol. 31, no. 8, pp. 20502056, 1997.

[15] S. Parsons, Advanced Oxidation Processes for Water and Wastewater Treatment, IWA publishing, Alliance House, London, UK, 2004

[16] C. Jiang, S. Pang, F. Ouyang, J. Ma, and J. Jiang, "A new insight into Fenton and Fenton-like processes for water treatment," Journal of Hazardous Materials, vol. 174, no. 1-3, pp. 813-817, 2010.

[17] M. D. Gurol and S. Lin, "Continuous catalytic oxidation processes,” US PATENT 5755977, 1998.
[18] S. Sabhi and J. Kiwi, "Degradation of 2,4-dichlorophenol by immobilized iron catalysts," Water Research, vol. 35, no. 8, pp. 1994-2002, 2001.

[19] Y. F. Han, N. Phonthammachai, K. Ramesh, Z. Zhong, and T. I. M. White, "Removing organic compounds from aqueous medium via wet peroxidation by gold catalysts," Environmental Science and Technology, vol. 42, no. 3, pp. 908-912, 2008.

[20] P. L. Huston and J. J. Pignatello, "Degradation of selected pesticide active ingredients and commercial formulations in water by the photo-assisted Fenton reaction," Water Research, vol. 33, no. 5, pp. 1238-1246, 1999.

[21] Y. Deng and J. D. Englehardt, "Treatment of landfill leachate by the Fenton process," Water Research, vol. 40, no. 20, pp. 36833694, 2006.

[22] A. Goi, Y. Veressinina, and M. Trapido, "Fenton process for landfill leachate treatment: evaluation of biodegradability and toxicity," Journal of Environmental Engineering, vol. 136, no. 1, pp. 46-53, 2010.

[23] T. Yilmaz, A. Aygün, A. Berktay, and B. Nas, "Removal of COD and colour from young municipal landfill leachate by Fenton process," Environmental Technology, vol. 31, no. 14, pp. 1635$1640,2010$.

[24] E. M. R. Rocha, V. J. P. Vilar, A. Fonseca, I. Saraiva, and R. A. R. Boaventura, "Landfill leachate treatment by solar-driven AOPs," Solar Energy, vol. 85, no. 1, pp. 46-56, 2011.

[25] S. Mohajeri, H. A. Aziz, M. H. Isa, M. A. Zahed, and M. N. Adlan, "Statistical optimization of process parameters for landfill leachate treatment using electro-Fenton technique," Journal of Hazardous Materials, vol. 176, no. 1-3, pp. 749-758, 2010.

[26] S. Navalon, R. Martin, M. Alvaro, and H. Garcia, "Gold on diamond nanoparticles as a highly efficient fenton catalyst," Angewandte Chemie-International Edition, vol. 49, no. 45, pp. 8403-8407, 2010.

[27] R. Martín, S. Navalon, M. Alvaro, and H. Garcia, "Optimized water treatment by combining catalytic Fenton reaction using diamond supported gold and biological degradation," Applied Catalysis B, vol. 103, no. 1-2, pp. 246-252, 2011.

[28] A. G. Chakinala, P. R. Gogate, A. E. Burgess, and D. H. Bremner, "Industrial wastewater treatment using hydrodynamic cavitation and heterogeneous advanced Fenton processing," Chemical Engineering Journal, vol. 152, no. 2-3, pp. 498-502, 2009.

[29] I. Oller, S. Malato, and J. A. Sánchez-Pérez, "Combination of Advanced Oxidation Processes and biological treatments for wastewater decontamination-A review," Science of the Total Environment, vol. 409, pp. 4141-4166, 2010.

[30] T. D. Nguyen, N. H. Phan, M. H. Do, and K. T. Ngo, "Magnetic $\mathrm{Fe}_{2} \mathrm{MO}_{4}$ (M:Fe, Mn) activated carbons: fabrication, characterization and heterogeneous Fenton oxidation of methyl orange," Journal of Hazardous Materials, vol. 185, no. 2-3, pp. 653-661, 2011.

[31] N. Panda, H. Sahoo, and S. Mohapatra, "Decolourization of Methyl Orange using Fenton-like mesoporous $\mathrm{Fe}_{2} \mathrm{O}_{3}-\mathrm{SiO}_{2}$ composite," Journal of Hazardous Materials, vol. 185, no. 1, pp. 359-365, 2011.

[32] L. A. Galeano, M. Á. Vicente, and A. Gil, "Treatment of municipal leachate of landfill by fenton-like heterogeneous catalytic wet peroxide oxidation using an $\mathrm{Al} / \mathrm{Fe}$-pillared montmorillonite as active catalyst," Chemical Engineering Journal, vol. 178, pp. 146-153, 2011.

[33] S. Bernal, J. Kaspar, and A. Trovarelli, "Recent progress in catalysis by ceria and related compounds-preface," Catal Today, vol. 50, pp. 173-173, 1999. 
[34] A. Trovarelli, Catalysis by Ceria and Related Materials, Imperial College Press, London, UK, 2002.

[35] A. Trovarelli, C. De Leitenburg, M. Boaro, and G. Dolcetti, "The utilization of ceria in industrial catalysis," Catalysis Today, vol. 50, no. 2, pp. 353-367, 1999.

[36] A. Trovarelli, C. De Leitenburg, and G. Dolcetti, "Design better cerium-based oxidation catalysts," Chemtech, vol. 27, no. 6, pp. 32-37, 1997.

[37] L. Vivier and D. Duprez, "Ceria-based solid catalysts for organic chemistry," ChemSusChem, vol. 3, no. 6, pp. 654-678, 2010.

[38] N. D. Tran, M. Besson, C. Descorme, K. Fajerwerg, and C. Louis, "Influence of the pretreatment conditions on the performances of $\mathrm{CeO}_{2}$-supported gold catalysts in the catalytic wet air oxidation of carboxylic acids," Catalysis Communications, vol. 16, no. 1, pp. 98-102, 2011.

[39] S. Yang, W. Zhu, Z. Jiang, Z. Chen, and J. Wang, "nfluence of the structure of $\mathrm{TiO}_{2}, \mathrm{CeO}_{2}$, and $\mathrm{CeO}_{2}-\mathrm{TiO}_{2}$ supports on the activity of Ru catalysts in the catalytic wet air oxidation of acetic acid," Rare Metals, vol. 30, pp. 488-495, 2011.

[40] J. J. Delgado, X. Chen, J. A. Pérez-Omil, J. M. RodríguezIzquierdo, and M. A. Cauqui, "The effect of reaction conditions on the apparent deactivation of $\mathrm{Ce}-\mathrm{Zr}$ mixed oxides for the catalytic wet oxidation of phenol," Catalysis Today, vol. 180, pp. 25-33, 2011.

[41] Y. Liu and D. Sun, "Effect of $\mathrm{CeO}_{2}$ doping on catalytic activity of $\mathrm{Fe}_{2} \mathrm{O}_{3} / \gamma-\mathrm{Al}_{2} \mathrm{O}_{3}$ catalyst for catalytic wet peroxide oxidation of azo dyes," Journal of Hazardous Materials, vol. 143, no. 1-2, pp. 448-454, 2007.

[42] R. C. Martins, N. Amaral-Silva, and R. M. Quinta-Ferreira, "Ceria based solid catalysts for Fenton's depuration of phenolic wastewaters, biodegradability enhancement and toxicity removal," Applied Catalysis B, vol. 99, no. 1-2, pp. 135-144, 2010.

[43] S. Silva Martínez, J. Vergara Sánchez, J. R. Moreno Estrada, and R. Flores Velásquez, "FeIII supported on ceria as effective catalyst for the heterogeneous photo-oxidation of basic orange 2 in aqueous solution with sunlight," Solar Energy Materials and Solar Cells, vol. 95, no. 8, pp. 2010-2017, 2011.

[44] P. A. Deshpande, D. Jain, and G. Madras, "Kinetics and mechanism for dye degradation with ionic Pd-substituted ceria," Applied Catalysis A, vol. 395, no. 1-2, pp. 39-48, 2011.

[45] APHA, AWWA, and WEF, Standard Methods for the Examination of Water and Wastewater, American Public Health Association, American Water Works Association, Water Environment Federation, Washington, DC, USA, 20th edition, 1999.

[46] R. Jenkins and R. Snyder, To X-Ray Powder Diffractometry, Wiley, New York, NY, USA, 1996.

[47] R. A. Young, The Rietveld Method IUCr, Oxford University Press, New York, NY, USA, 1993.

[48] A. C. Larson and R. B. V. Dreele, General Structure Analysis System 'GSAS', Los Alamos National Laboratory, 2000.

[49] B. H. Toby, "EXPGUI, a graphical user interface for GSAS," Journal of Applied Crystallography, vol. 34, no. 2, pp. 210-213, 2001.

[50] D. J. Kim, "Lattice-parameters, ionic conductivities, and solubility limits in fluorite-structure $\mathrm{MO} 2$ Oxide $[\mathrm{M}=\mathrm{Hf} 4+$, Zr4+, Ce4+, Th4+, U4+] Solid Solutions ," Journal of the American Ceramic Society, vol. 72, no. 8, pp. 1415-1421, 1989.

[51] E. Aneggi, M. Boaro, C. De Leitenburg, G. Dolcetti, and A. Trovarelli, "Insights into the redox properties of ceria-based oxides and their implications in catalysis," Journal of Alloys and Compounds, vol. 408-412, pp. 1096-1102, 2006.

[52] E. Mamontov, R. Brezny, M. Koranne, and T. Egami, "Nanoscale heterogeneities and oxygen storage capacity of Ce 0.5Zr0.5O2," Journal of Physical Chemistry B, vol. 107, no. 47, pp. 13007-13014, 2003.

[53] R. Q. Syed and W. Chiang, Sanitary Landfill Leachate, Generation, Control and Treatment, Technomic, Basel, Switzerland, 1994.

[54] J. Kaspar and P. Fornasiero, "Structural properties and thermal stability of ceria-zirconia and related materials," in Catalysis by Ceria and Related Materials, A. Trovarelli, Ed., Imperial College Press, London, UK, 2002.

[55] A. Trovarelli, F. Zamar, J. Llorca, C. De Leitenburg, G. Dolcetti, and J. T. Kiss, "Nanophase fluorite-structured $\mathrm{CeO}_{2}-\mathrm{ZrO}_{2}$ catalysts prepared by high-energy mechanical milling: analysis of low-temperature redox activity and oxygen storage capacity," Journal of Catalysis, vol. 169, no. 2, pp. 490-502, 1997.

[56] S. Rossignol, F. Gérard, and D. Duprez, "Effect of the preparation method on the properties of zirconia-ceria materials," Journal of Materials Chemistry, vol. 9, no. 7, pp. 1615-1620, 1999.

[57] H. Vidal, J. Kašpar, M. Pijolat et al., "Redox behavior of $\mathrm{CeO}_{2}$ $\mathrm{ZrO}_{2}$ mixed oxides. I. Influence of redox treatments on high surface area catalysts," Applied Catalysis B, vol. 27, no. 1, pp. 49-63, 2000.

[58] H. Vidal, J. Kašpar, M. Pijolat et al., "Redox ehaviour of $\mathrm{CeO}_{2}$ $\mathrm{ZrO}_{2}$ mixed oxides II. Influence of redox treatments on low surface area catalysts," Applied Catalysis B, vol. 30, no. 1-2, pp. 75-85, 2001.

[59] J. Kaspar, P. Fornasiero, G. Balducci, R. Di Monte, N. Hickey, and V. Sergo, "Effect of $\mathrm{ZrO}_{2}$ content on textural and structural properties of $\mathrm{CeO}_{2}-\mathrm{ZrO}_{2}$ solid solutions made by citrate complexation route," Inorganica Chimica Acta, vol. 349, pp. 217-226, 2003.

[60] P. Fornasiero, G. Balducci, R. Di Monte et al., "Modification of the redox behaviour of $\mathrm{CeO}_{2}$ induced by structural doping with $\mathrm{ZrO}_{2}$," Journal of Catalysis, vol. 164, no. 1, pp. 173-183, 1996.

[61] Z. Tianshu, P. Hing, H. Huang, and J. Kilner, "Sintering and densification behavior of $\mathrm{Mn}$-doped $\mathrm{CeO}_{2}$," Materials Science and Engineering B, vol. 83, no. 1-3, pp. 235-241, 2001.

[62] F. J. Pérez-Alonso, M. L. Granados, M. Ojeda et al., "Chemical structures of coprecipitated Fe-Ce mixed oxides," Chemistry of Materials, vol. 17, no. 9, pp. 2329-2339, 2005.

[63] A. Hiroki and J. A. LaVerne, "Decomposition of hydrogen peroxide at water-ceramic oxide interfaces," Journal of Physical Chemistry B, vol. 109, no. 8, pp. 3364-3370, 2005.

[64] A. Trovarelli, "Catalytic properties of ceria and $\mathrm{CeO}_{2}$ Containing materials," Catalysis Reviews, vol. 38, no. 4, pp. 439-520, 1996.

[65] Y. Madier, C. Descorme, A. M. Le Govic, and D. Duprez, "Oxygen mobility in $\mathrm{CeO}_{2}$ and $\mathrm{CexZr}_{(1-x)} \mathrm{O}_{2}$ compounds: study by CO transient oxidation and ${ }^{18} \mathrm{O} /{ }^{16} \mathrm{O}$ isotopic exchange," Journal of Physical Chemistry B, vol. 103, no. 50, pp. 1099911006, 1999.

[66] M. Boaro, C. De Leitenburg, G. Dolcetti, and A. Trovarelli, "The dynamics of oxygen storage in ceria-zirconia model catalysts measured by $\mathrm{CO}$ oxidation under stationary and cycling feedstream compositions," Journal of Catalysis, vol. 193, no. 2, pp. 338-347, 2000.

[67] C. E. Hori, H. Permana, K. Y. S. Ng et al., "Thermal stability of oxygen storage properties in a mixed $\mathrm{CeO}_{2}-\mathrm{ZrO}_{2}$ system," Applied Catalysis B, vol. 16, no. 2, pp. 105-117, 1998. 


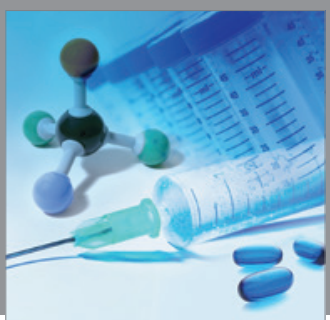

International Journal of

Medicinal Chemistry

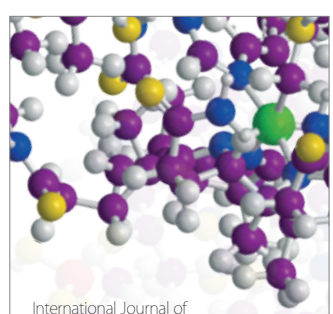

Carbohydrate Chemistry

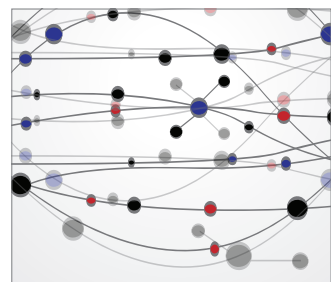

The Scientific World Journal
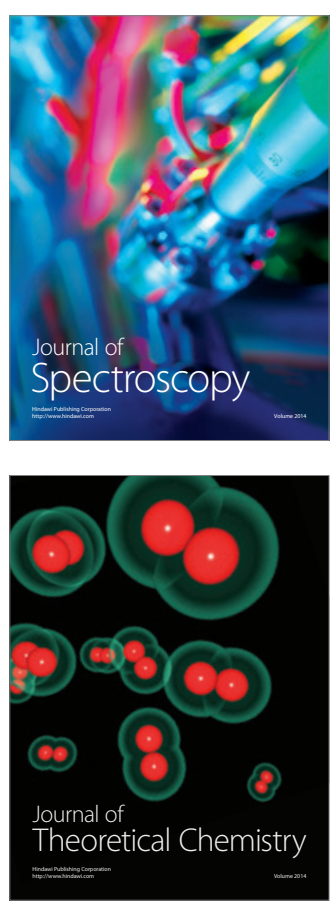
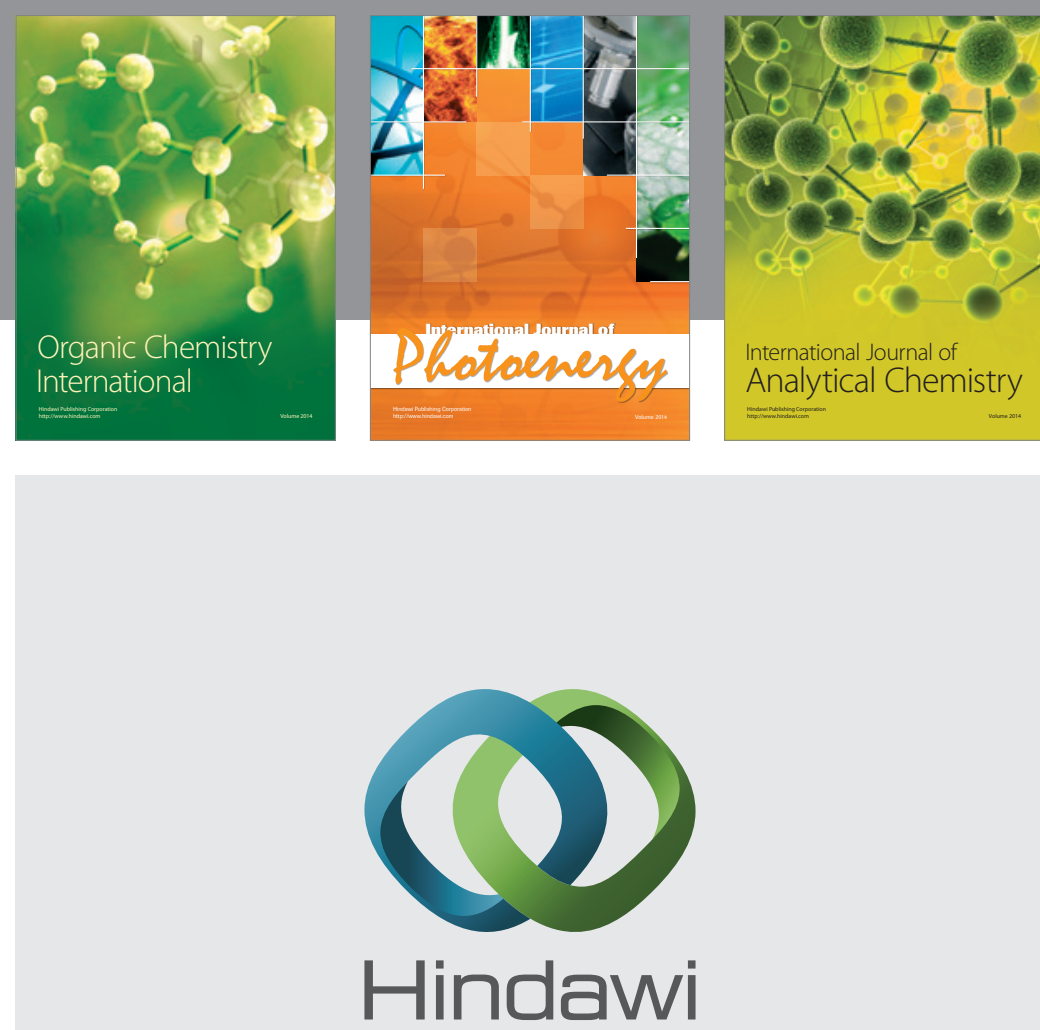

Submit your manuscripts at

http://www.hindawi.com
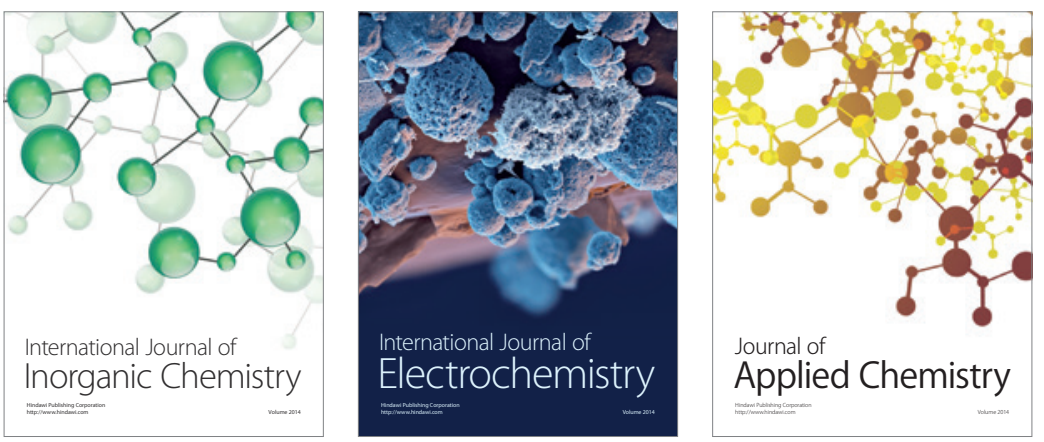

Journal of

Applied Chemistry
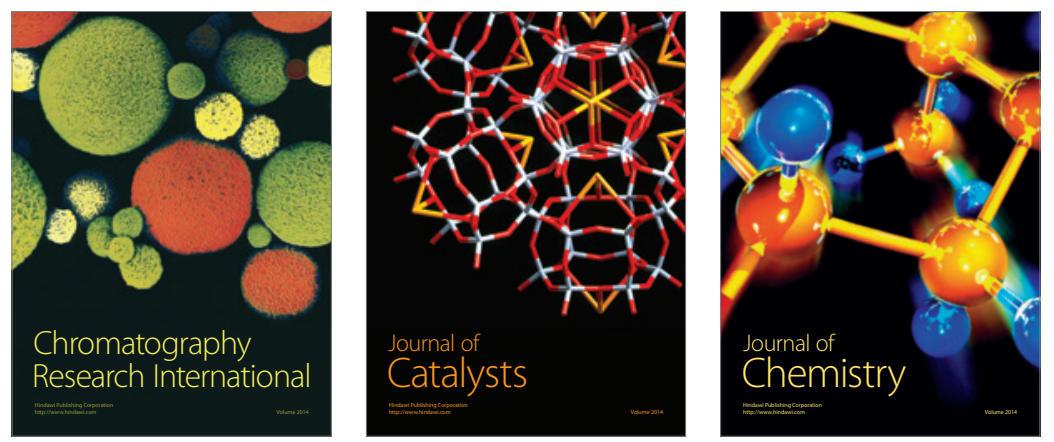
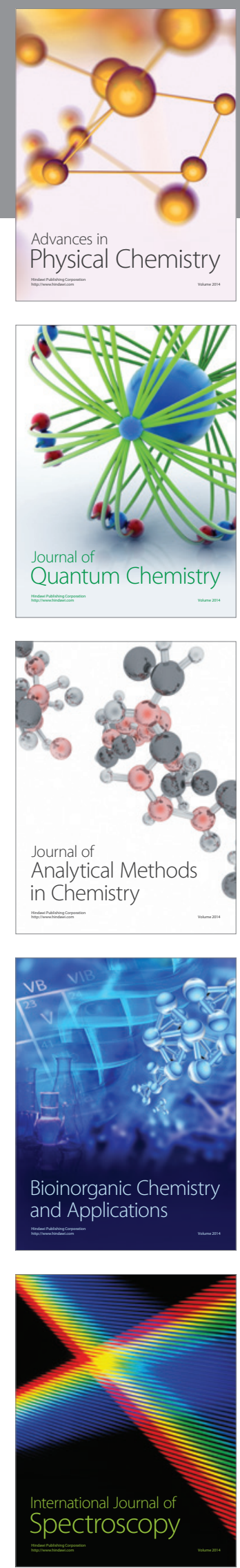